\title{
Effect of a New Design Electronic Control System on the Emissions Improve for Diesel Engine Operation by (Diesel + LPG)
}

\author{
Mohanad M. Al-kaabi ${ }^{1 *}$, Mudhaffar S. Al-Zuhairy ${ }^{2}$, Hyder H. Balla ${ }^{3}$ \\ ${ }^{1}$ Department of Power Mechanics, Technical College Najaf, Al-Furat Al-Awsat Technical University, Najaf 31001, Iraq \\ ${ }^{2}$ Department of Civil Engineering, Technical College Najaf, AI-Furat Al-Awsat Technical University, Najaf 31001, Iraq \\ ${ }^{3}$ Najaf Technical Institute, Al-Furat Al-Awsat Technical University, Najaf 31001, Iraq
}

Corresponding Author Email: hyderballa@atu.edu.iq

https://doi.org/10.18280/ijdne.150414

Received: 16 May 2020

Accepted: 11 June 2020

\section{Keywords:}

diesel engine, diesel fuel, dual-fuel, $L P G$, emission, $\mathrm{NOx}, \mathrm{HC}, \mathrm{CO}_{2}$

\begin{abstract}
Diesel engines are important and widely used in many fields in industry, agriculture transportation, and electricity, but the disadvantages of these engines are environmental pollution due to exhaust gas emissions as well as the high cost of diesel fuel. These defects made the topic an important research topic to search for less polluting and less expensive fuel to use it in diesel engines, and this makes LPG a good candidate for diesel supplements because it contains several technical advantages in this regard, being environment friendly and has a high heat value to increase energy production And also its price is cheap compared to diesel fuel. In this study, an electronic system was designed to control the LPG injector and a magnetic sensor was installed on top of a single-cylinder and air-cooled diesel engine head. Tested using at two-stage first diesel fuel D-100 and second stage, dual-fuel in three modes (LPG-25, LPG-50, and LPG-75). The test was under loads $(0 \%, 25 \%, 50 \%, 75 \%$ and 100\%) at different speeds $(1000,1500$ and 2000 $\mathrm{rpm})$. A decrease in emission ratios ( $\mathrm{NOx}, \mathrm{HC}, \mathrm{CO}$, and $\left.\mathrm{CO}_{2}\right)$ is observed in all operating modes with LPG, and the best emission reduction mode is LPG-75. As for $\mathrm{O}_{2}$ gas, the results showed almost the same in diesel case.
\end{abstract}

\section{INTRODUCTION}

Due to the rapid increase in the population around the world increased demand for internal combustion engines, especially for diesel engines compared to other types of engines in the same size range it has a large capacity for high use in transportation, irrigation, electricity generation, and heavy industries. Based on the widespread use of diesel engines and the protection placed on the production of diesel engines is increasing year on year and the transport sector is accountable around $35 \%$ of pollutant emissions [1] and approximately 20$30 \%$ of all consumption of energy [2]. Significant research is being carried out on diesel engines which develop fuels. CI engines release different types of pollutants like NOx, HC, CO2, CO, particles, soot particles, etc. [1, 3-5]. Regardless of the other parameters of the engine, the emission results from the phenomenon of the combustion process and the chemistry of the fuel used. By using biodiesel and gaseous fuel additives. There are several studies on diesel engines to boost engine efficiency and reduce harmful emissions by using alternative fuels. Exhaust emissions from the $\mathrm{CI}$ engine are harmful to our respiratory system, and also effective on environment pollution [4, 6-14]. In addition to engine parameters, the emission depends on the combustion process and the chemistry used for the fuel. The use of biodiesel and gaseous fuel additives will significantly reduce these emissions. LPG is one of the leading alternative fuels. LPG is safer than petrol and diesel, as it consists mainly of simple hydrocarbon compounds. LPG contains very little sulfur and is free of lead and most additives [15-17]. Compared with vehicle emissions of petrol and diesel, LPG-driven vehicle emissions include lower levels of hydrocarbon compounds (HC), nitrogen oxides (NOx), sulfur oxides, Air toxics, and particulate matter [18].

There are two ways to keep pollution under control [1]. The first approach is to monitor emissions after combustion, using different devices at the exit point such as catalytic converters, thermal converters, etc. The second method, which is to regulate emissions during combustion. This can be accomplished either by modifying the fuel injection timing or by adding some external additives that can operate inside the combustion chamber and produce clean exhaust. Typically only about 82 percent of fuel burns entirely in typical diesel engines [19] by adding LPG to the combustion process, it is possible to burn nearly 98 percent of fuel. Emissions issues such as Particulate Matters (PM) and NOx are now well known to be mainly associated with diesel engines. These emissions can be reduced substantially with the use of LPG. Compared to natural gas, LPG has the advantage of lowpressure fuel, ease of transport, and better handling. LPG can be used as an alternative fuel in spark-ignition engines as well as in dual-fuel usage as an alternative fuel for the compression ignition engines with diesel. The relatively high auto-ignition temperature of the LPG is an advantage that allows the compression ratio of conventional diesel engines to be maintained and minimal modifications to the engine to be made. It has the potential for significant savings in diesel fuel and increased system power [20, 21]. The response of the engine is smoother and faster when the gas is added and the replacement is high. The service schedule may be extended due to the fumigation of gaseous fuel, reduced injection 
service, and longer oil change intervals due to less contamination of engine oil [15].

The extraction of many natural gas liquids (NGL) in many gas fields in increased the country's capacity to produce liquefied petroleum gas. In the spark ignition engines investigated by Chiriac et al. [22] and Ehsan et al. [23], LPG was successfully used, but the dual-fuel operation in the diesel engine was relatively less investigated. Jian, et al. [24] A new type of dual system has been developed that could effectively turn traditional diesel engines into dual-fuel engines (LPG+Diesel engines and CNG+Diesel engines), using either only diesel or dual-fuel, A diesel and LPG as well as diesel and CNG engines. These diesel-LPG engines were applied to the diesel busses in Guangzhou City's public transport, one of China's largest cities. Compared to the diesel baseline engine, it was found that soot emissions were significantly reduced and fuel consumption improved with the diesel+LPG engine. The LPG commodity strategy is also tackled to meet the demands of soot emission, fuel efficiency, transient performance, and output power simultaneously. Rao and others $[6,25,26]$. Experimental tests were performed on a single-cylinder water-cooled ignition compression engine operating in dual-fuel mode with diesel as pilot fuel and LPG as the main fuel. The engine was run under different operating conditions and for the best efficiency, the optimal combination of the proportions induced to inject fuel energy is calculated in each case [8, 27, 28].

Salman et al. [29] investigated the reduction in the emission of exhaust gas from a dual-fuel diesel engine. For this reason, a single-cylinder, the direct-injection diesel engine was converted into dual-fuel operation (70\% diesel and 30\% LPG by weight). The engine speed was maintained constant (1650 rpm) during the experiments and the load was changed. In several studies carried out by Qi et al. and Vijayabalan et al. [30, 31], about 40 to 65 percent of diesel replacement by LPG was observed depending on engine specification. Studies have shown that Diesel+LPG dual operations can achieve the rated capacity of traditional diesel engines, up to a point of diesel replacement [30, 31]. Saleh [32] has shown that both environmental and economic benefits of dual fuel service with LPG. Kumar and Azad [11] Modified diesel genet for operation with dual fuel, LPG and diesel genet. In addition to emissions testing, the engine performance test was carried out on the updated diesel genet at different quantities of diesel and LPG including $100 \%$ diesel. The test result showed that the BTE and BSFC are increased by $30 \%$ at full load condition at a blend of $30 \%$ LPG and $70 \%$ diesel, while the fuel consumption cost is $22 \%$ lower than the peak load cost of a $100 \%$ diesel._In addition, emissions such as $\mathrm{NO}_{\mathrm{x}} \&$ Smoke decreased at full load condition by $33 \%$ and $28 \%$. Yuvaraj [12] experiment done on a traditional dual fuel $\mathrm{CI}$ engine using diesel and LPG. The experiment by a diesel engine, direct injection, single cylinder, 4-stroke,water cooling. The LPG tank is sent into the inlet manifold at a rate of $0.25 \mathrm{~kg} / \mathrm{hr}$ using LPG valve with the help of the pressure regulator. The results of the experiment showed reduction of Carbon monoxide $(\mathrm{CO})$, Carbon dioxide $\left(\mathrm{CO}_{2}\right)$ Hydrocarbon $(\mathrm{HC})$, Nitric oxide $\left(\mathrm{NO}_{\mathrm{x}}\right)$, Oxygen $\left(\mathrm{O}_{2}\right)$ emissions than the diesel engine. Reduced the emission. The brake thermal efficiency for LPG-diesel mode increases as load increases gives more than $3 \%$ of better performance compare to the pure diesel engine. Specific fuel consumption reduced when compared to the pure diesel fuel (the pure diesel consume of $0.8 \mathrm{~kg} / \mathrm{Kw} \cdot \mathrm{hr}$, the blend fuel consume fuel $0.78 \mathrm{Kg} / \mathrm{Kw} . \mathrm{hr}$ ). Karim [33] stressed the importance of understanding the mechanisms of combustion at dual-fuel engines in terms of increased engine performance and reduced air pollution. Given that Iraq produces primarily accompanying natural gas and that its production of crude oil reached 4.4 million barrels per day (MMb/d) in January 2018 (the second producer of crude oil in OPEC) [34]. Using LPG as an alternative motor fuel requires relatively small and not costly adaptations in spark-ignited motors. They found the economic and ecological benefits of using these engines, and more often sell vehicles with Autogas systems built in the factory. It creates a positive image of Autogas as an environmentally friendly, cost effective and fully safe fuel [16, 35]. This is a very positive indication of the possibility of using liquefied gas as a dual fuel with diesel being available in this country Iraq as well as from material and economic foreigners and it can be produced according to what the combustion process requires in internal combustion engines [13].

In this study, dual-fuel engine is used where diesel is used as an elementary fuel and LPG is used as a subsidiary fuel. Here a diesel+LPG engine is addressed which can either use single diesel fuel or use diesel-LPG fuel. LPG is operated by a new electronic system designed to suit the diesel engine's function-LPG after making an engine change and installing a magnetic sensor on the engine's head. The engine was initially run on the base diesel mode and the test engine was operated with four different fuel types as D-100, LPG-25, LPG-50, and LPG-75 using an air valve to enter the LPG with the air into the combustion chamber and at the pressure 1 bar. The pure quantity of diesel was modified by is the flow rate of the injectors $(100 \%, 75 \%, 50 \%$, and $25 \%)$ and replaced by LPG. The test was for each condition loads $(0 \%, 25 \%, 50 \%, 75 \%$ and $100 \%)$ at different speeds $(1000,1500$ and 2000) rpm.

\section{MATERIALS AND METHODS}

Table 1. The characteristics of commonly used fuels

\begin{tabular}{cccc}
\hline $\begin{array}{c}\text { S. } \\
\text { No. }\end{array}$ & Properties & Diesel & LPG \\
\hline 1 & Normal state & Liquid & Gaseous \\
1 & Formula & C9.12H16.85 & C3.34H8.68 \\
2 & Density $(\mathrm{kg} / \mathrm{m} 3) @ 15^{\circ} \mathrm{C}$ & 870 & 550 \\
3 & Boiling Point, ${ }^{\circ} \mathrm{C}$ & $160-320$ & -34 \\
4 & Flashpoint, ${ }^{\circ} \mathrm{C}$ & $>52$ & -140 \\
5 & Auto Ignition & $242-257$ & 525 \\
\hline
\end{tabular}

Table 2. Specifications of the engine used

\begin{tabular}{|c|c|c|}
\hline Brand & & LOMBARDINI, ITALY \\
\hline Type & & 15LD315 \\
\hline Injector type & & Direct injection \\
\hline Engine type & & Single-cylinder 4-stroke \\
\hline Cooling type & & Air-cooled \\
\hline Cylinders & $\mathrm{N}$ & 1 \\
\hline Displacement & $\mathrm{cm}^{3}$ & 315 \\
\hline Bore & $\mathrm{mm}$ & 78 \\
\hline Stroke & $\mathrm{mm}$ & 60 \\
\hline Compression ratio & & 20.3:1 \\
\hline Max. Power & & $5.0 \mathrm{~kW} / 6.8 \mathrm{HP}$ \\
\hline Dryweight & $\mathrm{kg}$ & 33 \\
\hline Max.Torque & $\mathrm{Nm}$ & $15 @ 2400$ \\
\hline Rated speed & $\mathrm{rpm}$ & 3600 \\
\hline Dimension (LxWxH) & $\mathrm{mm}$ & $295 \times 374 \times 445$ \\
\hline Method of starting & & Hand cranking \\
\hline
\end{tabular}


In the experiment, was diesel and LPG fuel used as test fuels. LPG content was Iraqi liquefied petroleum gas (LPG) is a three-gas mixture of $0.05 \mathrm{C}_{2} \mathrm{H}_{6}$ (Ethane), $0.5 \mathrm{C}_{3} \mathrm{H}_{8}$ (Propane), and $0.45 \mathrm{C}_{4} \mathrm{H}_{10}$ (Butane). The properties of the test fuels (diesel and LPG) are given in the Table 1. The engine used in this experiment is a single-cylinder direct-injection four-stroke, the air-cooled diesel engine was used to experiment. Brief specification at a Table 2 .

\subsection{Diesel injection system}

The amount of diesel fuel entering the combustion chamber is controlled by special nozzles worked according to the proportions $(25 \%, 50 \%, 75 \%$, and $100 \%)$ as shown in Figure 1 and in each special experiment, the type of nozzles was used where the engine is running in each one of the above cases, and the LPG is entered by the electronic control unit.

\subsection{Electronic control unit for LPG}

This electronic system controls the time and amount of gas entering the engine via the injector and takes the signal through a magnetic sensor installed on the motorhead as shown in Figure 2 and connected to a source 12-volt DC. The engine is modified by a magnetic sensor installed mount that signal the electronic control unit of the LPG system that controls the amount and time of the LPG at the intake manifold and mixes it with the air entering the combustion chamber of the engine at pressure 1 bar as shown in the Figure 3.

\begin{tabular}{|c|c|c|c|}
\hline 1 & 2 & 3 & 4 \\
\hline $100 \%$ & $75 \%$ & $50 \%$ & $25 \%$ \\
\hline 4 & 9 & 3 & 4 \\
\hline 11 & 4 & & \\
\hline
\end{tabular}

Figure 1. Types of injectors the pure diesel used

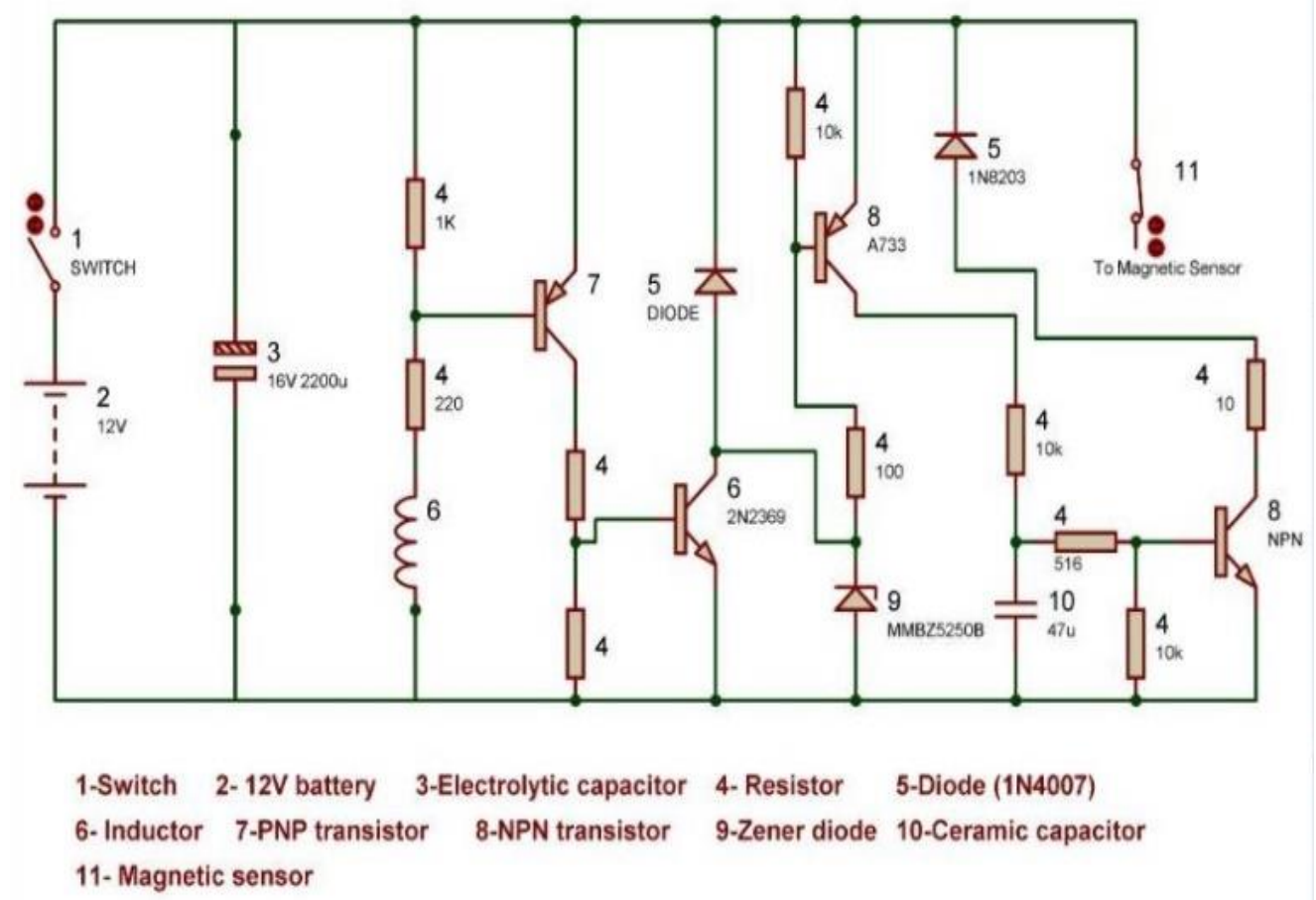

Figure 2. Diagram of electronic control unit

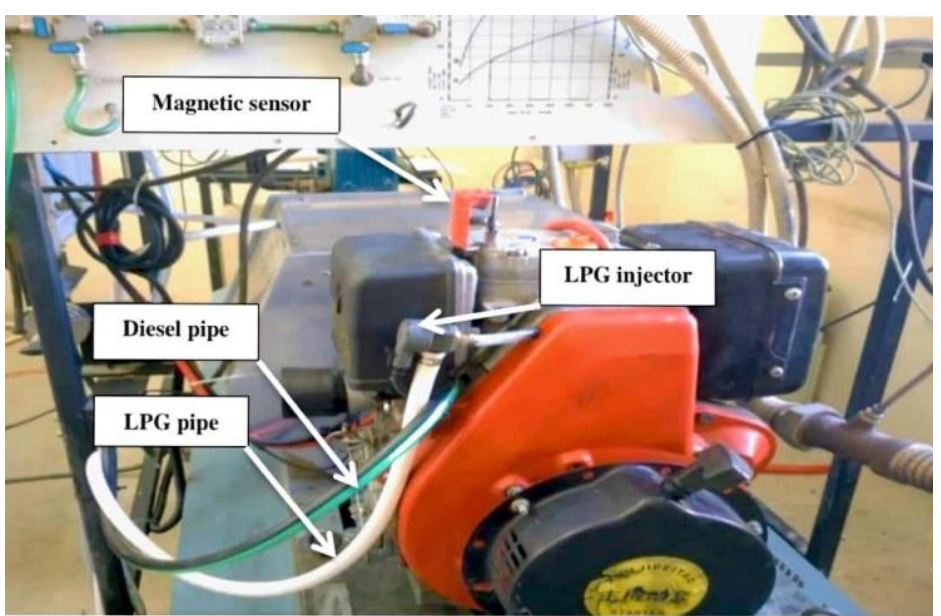

Figure 3. Experiment engine with parts 


\section{EXPERIMENTAL METHODOLOGY}

A schematic setup diagram is shown in Figure 4. This explains the parts of the experiment and a special electronic system was designed for LPG, then the set was run in the mode of diesel fuel only and the readings were taken, and then the engine was started using LPG. Therefore, a partial engine modification of the gas vaporizer was applied. Crossflow mixing chamber before the inlet valve is combined to mix LPG with air.

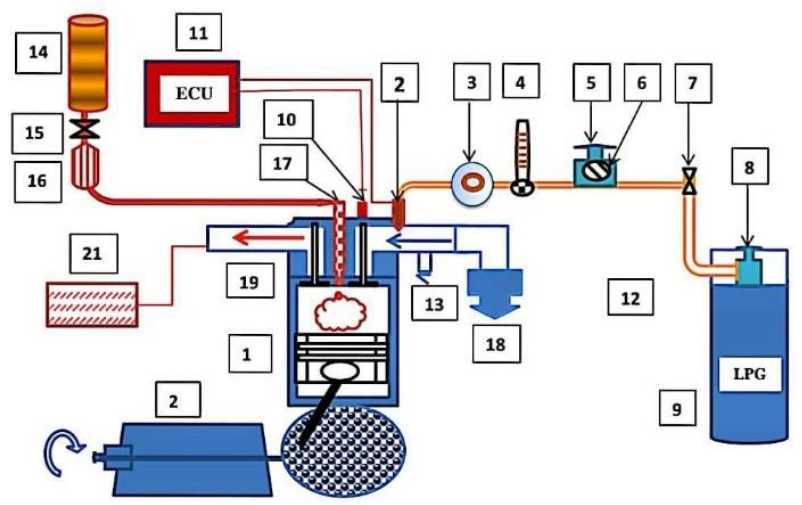

1-Test engine; 2- LPG injector; 3- Vaporizer; 4-Flow meter for LPG; 5Pressure regulator; 6- Pressure gage; 7-Valve for LPG; 8-Pressure valve; 9LPG cylinder; 10-Magnetic sensor ;11- Electronic control unit for LPG; 12 Air filter; 13-Air manometer; 14- Diesel flow meter; 15- Diesel valve; 16Diesel filter; 17- Diesel injector; 18-Intake; 19-Exhaust; 20- Dynamometric unit; 21- Gas Analysis Unit

Figure 4. Block diagram of the experimental setup

\section{RESULTS AND DISCUSSION}

At the beginning of the experiment, the diesel engine was started in pure diesel fuel (D-100), and exhaust gas emissions were recorded in this mode, and then LPG was used in different proportions LPG-25, LPG-50 and LPG-75 at different loads $(0 \%, 25 \%, 50 \%, 75 \%$, and $100 \%)$ and at different engine speeds (1000, 1500 and 2000) rpm and the amount of LPG are controlled by an (ECU) and the readings were recorded as shown below:

\subsection{Nitrogen oxide emissions (NOx)}

Nitric oxide is a colorless, toxic gas that causes harmful hazards to the environment hence its emission from the dualfuel engine should be limited [12]. The emission of NOx from LPG of dual-fuel engine is lower than that compared to the pure diesel. Figure 5 shows the variations of NOx. High NOx emissions were observed under higher loads due to the temperature that decreased during expansion and exhaust strokes. The largest amount of nitrogen oxides appears in the exhaust at the highest elevation of loads and with an increase in engine speeds. where the results showed the highest increase in pure diesel D-100.

Figure $5 \mathrm{a}, \mathrm{b}$, and $\mathrm{c}$ show the differences in nitrogen oxides in different loads $(0 \%, 25 \%, 50 \%, 75 \%$ and $100 \%)$. Where it increases when the load increases in NOx at (LPG-25, LPG50, and LPG-75). As explained below in detail:

(1) Figure 5 a show the difference in nitrogen oxides at (1000 rpm), from the calculations, and the figure shown below, that nitrogen oxides decrease by $(3.8 \%, 3.198 \%$, and $7.65 \%)$ at mode LPG-25, LPG-50, and LPG-75 respectively compared with the D-100.

(2) Figure $5 \mathrm{~b}$ show the difference in nitrogen oxides at (1500 rpm), from the calculations, and the figure shown below, that nitrogen oxides decrease by $(7.57 \%, 18.18 \%$, and $22.7 \%)$ at mode LPG-25, LPG-50, and LPG-75 respectively compared with the D-100.

(3) Figure $5 \mathrm{c}$ show the difference in nitrogen oxides at (2000 rpm), from the calculations, and the figure is shown below, that nitrogen oxides decrease by $(4.82 \%, 10.38 \%$, and $21.5 \%$ ) at mode LPG-25, LPG-50, and LPG-75, respectively compared with D-100.

These findings are consistent with other studies $[6,12,26]$.
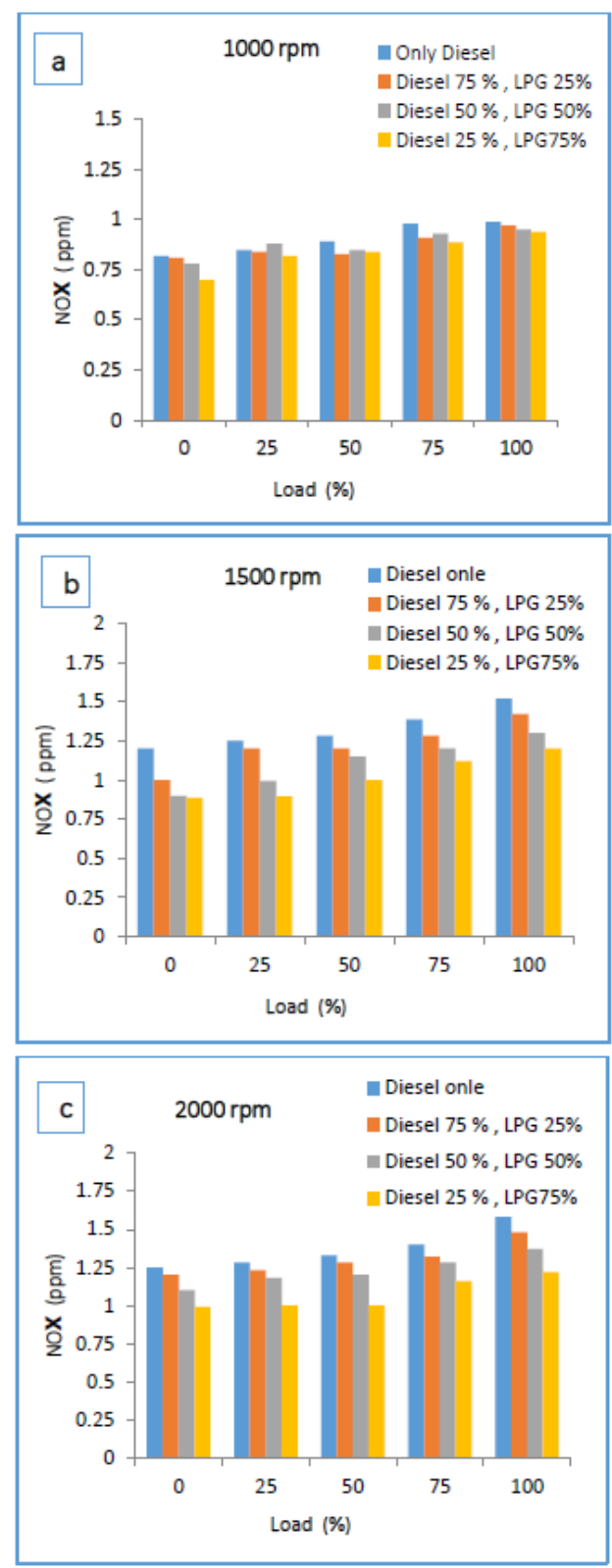

Figure 5. NOx emission variance, depending on engine load

\subsection{Hydrocarbon emissions (HC)}

The emission of unburned hydrocarbon (HC) comes from the combustion of part of the fuel injected into the engine. HC emissions rely on many mechanisms such as oil layer adsorption and desorption of fuel, flame quenching, fuel leakage into crevices, and fuel deposition in engine deposits, 
etc. HC emission values depend on the speed engine and load between (1000-2000) rpm and (0\%-100\%) respectively are given in Figure 6. HC emissions using different LPG ratios have decreased through improved combustion reactions with diesel pilot fuel and more effective combustion reactions with the help of LPG. As explained below in detail:

(1) Figure 6a shows the difference in $\mathrm{HC}$ at $(1000 \mathrm{rpm})$, from the figure shown below, that $\mathrm{HC}$ decrease by $(6.75 \%$, $12.93 \%$, and $18.3 \%$ ), respectively at the mode LPG-25, LPG50 and LPG-75 compared with the D-100.

(2) Figure $6 \mathrm{~b}$ shows the difference at $(1500 \mathrm{rpm})$, from the calculations, and the figure is shown below, that HC decrease by $(8.3 \%, 13 \%$, and $26 \%$ ), respectively at the mode LPG-25, LPG-50 and LPG-75 compared with the D-100.

(3) Figure 6c shows the difference in HC at $(2000 \mathrm{rpm}$, from the calculations, and the figure is shown below, that $\mathrm{HC}$ decrease by $(11.94 \%, 18 \%$, and $23.6 \%)$, respectively at the mode LPG-25, LPG-50, and LPG-75 compared with the D100.

Similar results were obtained by other studies [7, 36-38].
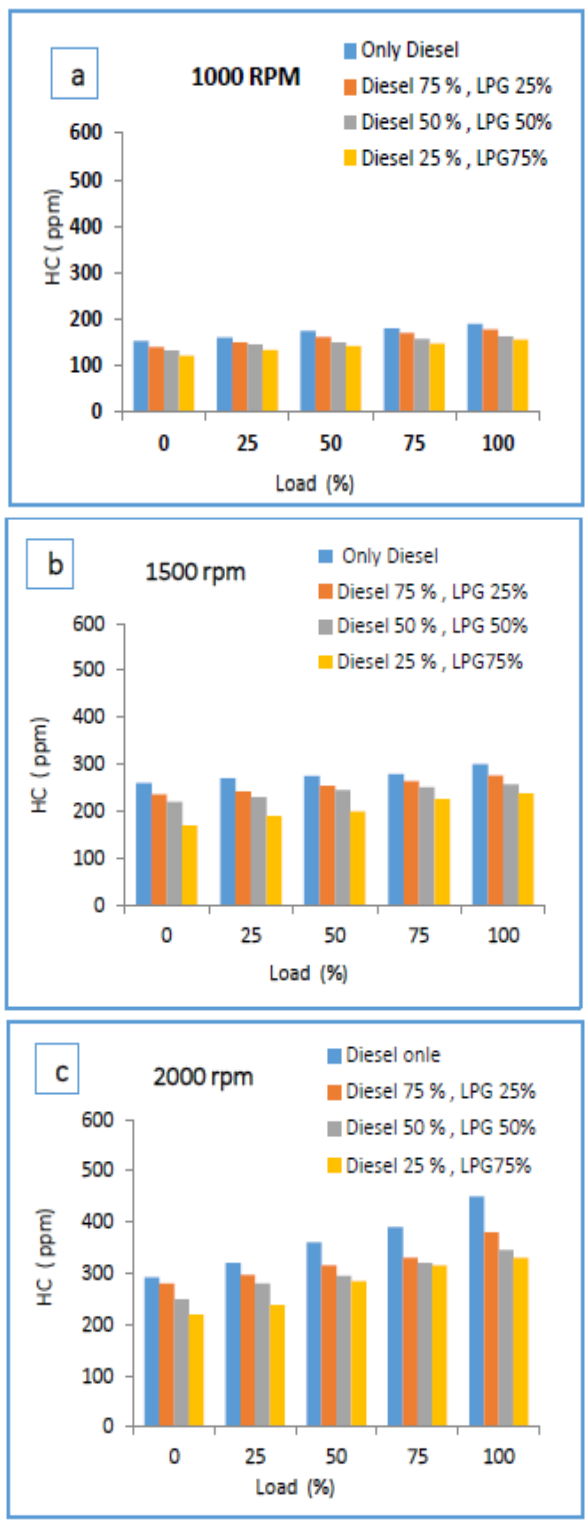

Figure 6. the $\mathrm{HC}$ emission range by depending on engine load

\subsection{Carbon monoxide emissions (CO)}

Carbon monoxide, which is the combination of one carbon atom and one oxygen atom is a poisonous gas that causes harmful hazards to the environment hence its emission from the dual-fuel engine should be limited. The emission of $\mathrm{CO}$ from LPG of the dual-fuel engine is less as compared to the pure diesel and as shown in Figure 7 where we note the following:

(1) Figure 7a shows the difference in $\mathrm{CO}$ at $(1000 \mathrm{rpm})$, from the calculations, and the figure is shown below, the $\mathrm{CO}$ at the mode LPG-25, LPG-50, and LPG-75 decrease by $(21.875 \%, 42.96 \%$, and $44.14 \%)$, respectively compared with the D-100.

(2) Figure $7 \mathrm{~b}$ shows the difference in $\mathrm{CO}$ at $(1500 \mathrm{rpm})$, from the calculations, and the figure is shown below, the $\mathrm{CO}$ at the mode LPG-25, LPG-50, and LPG-75 decrease by (16\%, $23.21 \%$, and $42.5 \%$ ), respectively compared with the D-100.

(3) Figure $7 \mathrm{c}$ shows the difference in $\mathrm{CO}$ at (2000 rpm), from the calculations, and the figure is shown below, the $\mathrm{CO}$ at the mode LPG-25, LPG-50, and LPG-75 decrease by (9.8\%, $14.84 \%$, and $21 \%$ ), respectively compared with the D-100
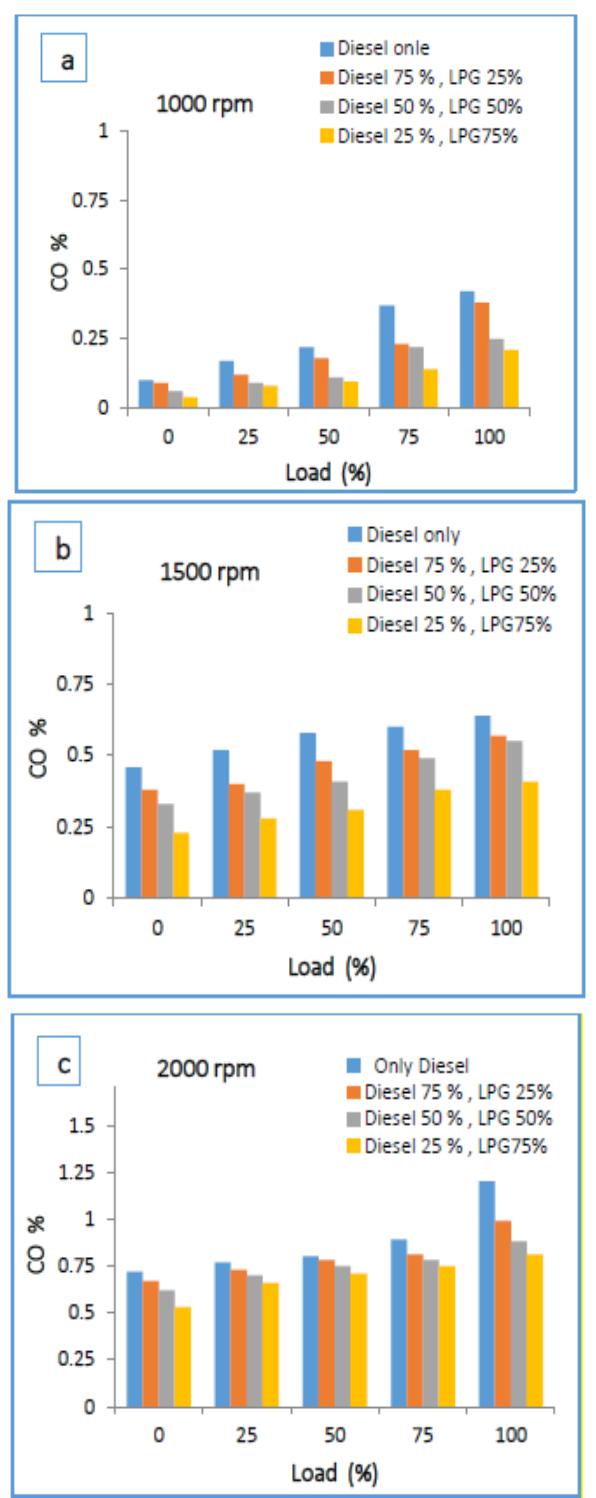

Figure 7. Variation of $\mathrm{CO}$ emission range by depending on load 


\subsection{Carbon dioxide emissions $\left(\mathrm{CO}_{2}\right)$}

Carbon dioxide is a poisonous gas that causes harmful hazards to the environment and emission from the dual-fuel engine should be limited. The emission of $\mathrm{CO}_{2}$ from LPG of the dual-fuel engine is lower than that compared to the pure diesel. Figure 8 shows the variations of $\mathrm{CO}_{2}$ emissions. As the loads on the engine and engine speed were increased the percentage of $\mathrm{CO}_{2}$ at diesel fuel and it reduces the increase in the percentage of LPG, as follows:

(1) Figure $8 \mathrm{a}$ shows the difference in $\mathrm{CO}_{2}$ at $(1000 \mathrm{rpm})$, from the calculations, and the figure is shown below, that decrease by $(16 \%, 22.37 \%$, and $27.76 \%)$ at the mode LPG-25, LPG-50, and LPG-75 respectively compared with the D-100

(2) Figure $8 \mathrm{~b}$ shows the difference in $\mathrm{CO}_{2}$ at $(1500 \mathrm{rpm})$, from the calculations, and the figure is shown below, that $\mathrm{CO} 2$ decrease by $(9.41 \%, 24.7 \%$, and $29.41 \%)$ at the mode LPG- 25 , LPG-50, and LPG-75 respectively compared with the D-100

(3) Figure $8 \mathrm{c}$ shows the difference in $\mathrm{CO}_{2}$ at $(2000 \mathrm{rpm})$, from the calculations, and the figure is shown below, that $\mathrm{CO}_{2}$ decrease by $(9.5 \%, 16.5 \%$, and $25 \%)$ at the mode LPG-25, LPG-50, and LPG-75 respectively compared with the D-100.

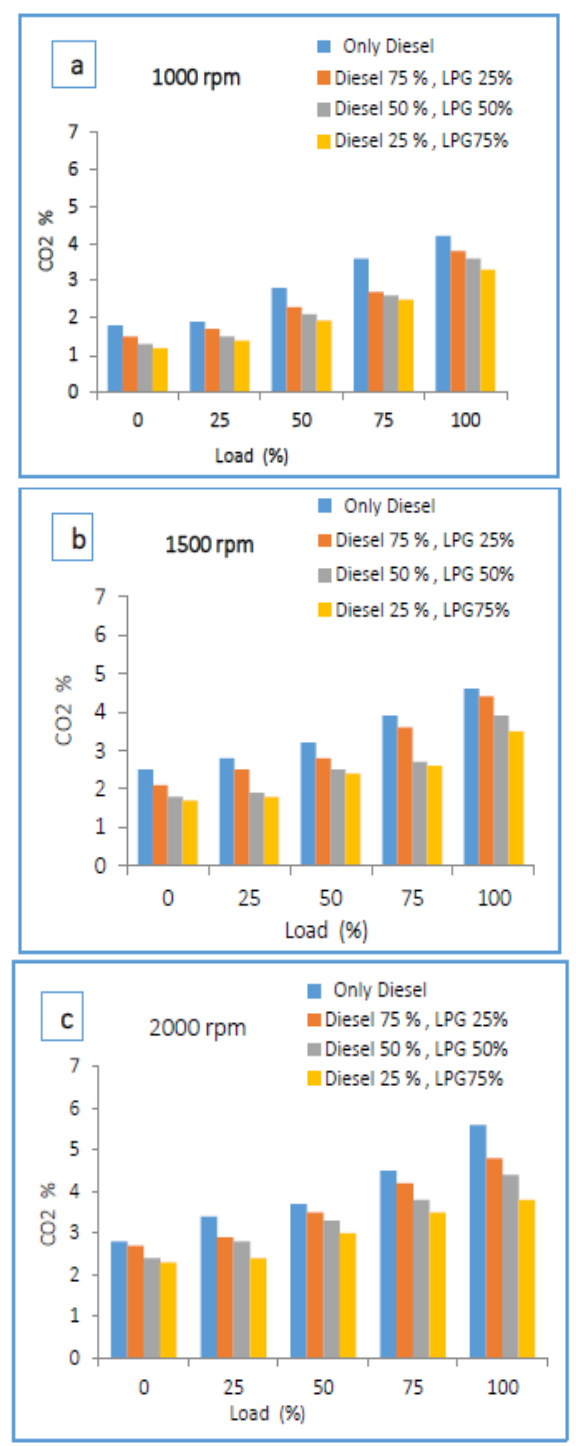

Figure 8. Variation of $\mathrm{CO}_{2}$ emission range by depending on load

In general, $\mathrm{CO}_{2}$ emissions were caused by the full combustion of a large amount of fuel at the cylinder and on the other hand, the $\mathrm{CO}$ emissions that occurred in the remaining fuel from all combustion were burned insufficiently. The noncombustible part of the fuel produced using $\mathrm{HC}$ emissions. The reasons why $\mathrm{CO}$ and $\mathrm{HC}$ emissions are produced are very similar. The direct injection of LPG fuel in the cylinder by an injector under is pressure enabled the LPG to achieve a better atomization level compared to the pure diesel fuel. Improving the combustion reaction with the use of the LPG fuel, thus produced a reduction in $\mathrm{CO}$ emissions. Better combustion and higher LPG calorific value enhance the flaming propagation and oxidation reactions which slightly reduce $\mathrm{HC}$ and $\mathrm{CO}$ emissions. Also, the lower LPG $\mathrm{C} / \mathrm{H}$ ratio decreases $\mathrm{HC}$ and $\mathrm{CO}$ emissions, and $\mathrm{CO}_{2}$ emissions. Those findings indicate with other studies [4, 32, 36, 39].

\subsection{Oxygen $\left(\mathrm{O}_{2}\right)$}

Oxygen is the most abundant element on the earth. The emission of $\mathrm{O}_{2}$ from LPG of a dual-fuel engine is the same as compared to the pure diesel at low load, but at maximum load and engine speed running condition of the engine, the emission of $\mathrm{O}_{2}$ in LPG diesel decreases than pure diesel operation. As shown in Figure 9 a, b, and c.
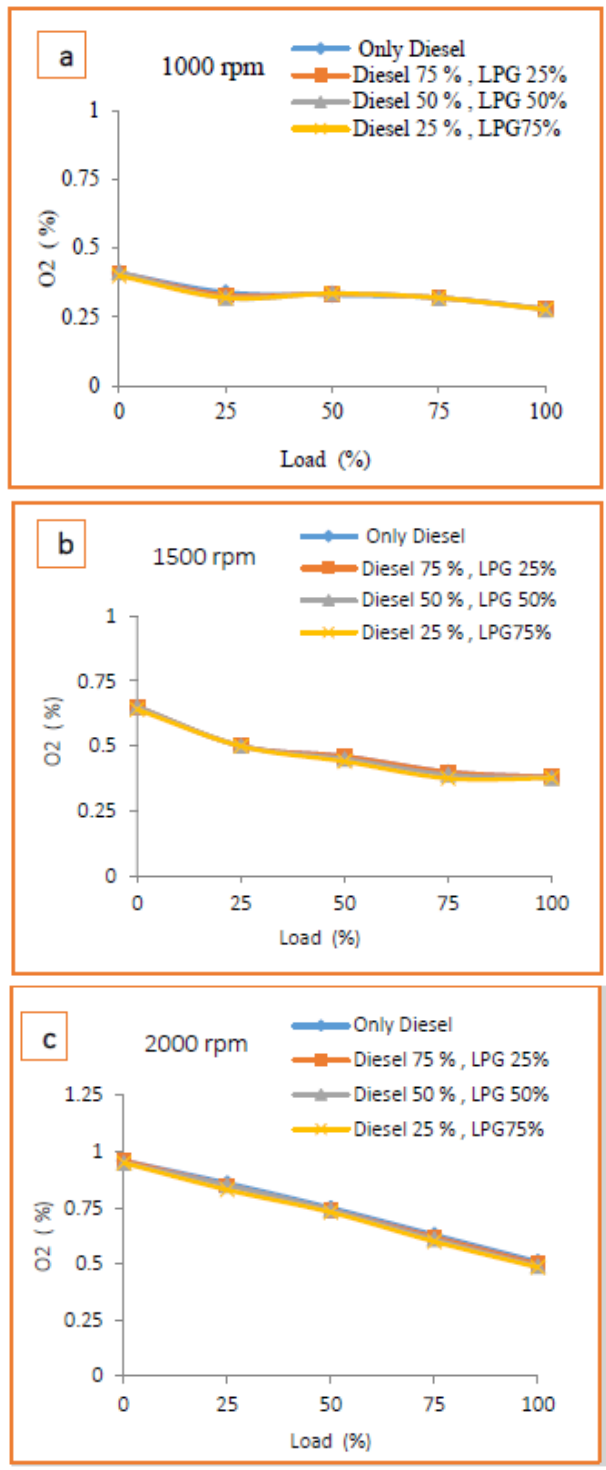

Figure 9. Variation of $\mathrm{O}_{2}$ emission depending on loads 


\section{CONCLUSIONS}

The following conclusions can be taken from the current study:

(1) A diesel engine can be successfully produced to run on dual fuel (Diesel + LPG) and a dual-fuel engine is ideal for all applications that a diesel engine can satisfy.

(2) When the engine runs on the dual-fuel show results in better emissions than diesel.

(3) The design of the electronic system contributed to controlling the amount of liquefied petroleum gas and injecting gas promptly, and this led to a reduction in fuel consumption and the implementation of safety requirements in the experiment.

(4) The best operating mode to reduce emissions is (LPG75), as it contributed to reducing emission ratios by proportions as shown below for each gas.

A-NOx reduced $(7.65 \%$ at $1000 \mathrm{rpm}, 22.7 \%$ at $1500 \mathrm{rpm}$ and $21.5 \%$ at $2000 \mathrm{rpm})$

B- $\mathrm{HC}$ reduced $(18.3 \%$ at $1000 \mathrm{rpm}, 26 \%$ at $1500 \mathrm{rpm}$ and $23.6 \%$ at $2000 \mathrm{rpm})$

C- $\mathrm{CO}$ reduced $(44.14 \%$ at $1000 \mathrm{rpm}, 42.5 \%$ at $1500 \mathrm{rpm}$ and $21 \%$ at $2000 \mathrm{rpm}$ )

D-CO2 reduced $(27.76 \%$ at $1000 \mathrm{rpm}, 24.41 \%$ at 1500 rpm and $25 \%$ at $2000 \mathrm{rpm})$

(5) The emission of $\mathrm{O}_{2}$ from LPG of the dual-fuel engine is the same as compared to the pure diesel.

\section{REFERENCES}

[1] Reşitołlu, I.A., Altinişik, K., Keskin, A. (2015). The pollutant emissions from diesel-engine vehicles and exhaust aftertreatment systems. Clean Technologies and Environmental Policy, 17(1): 15-27. https://doi.org/10.1007/s10098-014-0793-9

[2] Potter, S. (2003). Transport energy and emissions: urban public transport. In: Hensher, David and Button, Kenneth eds. Handbook of transport and the environment, 4. Handbooks in Transport. Amsterdam, Netherlands: Elsevier, pp. 247-262.

[3] Johnson, T. (2008). Diesel engine emissions and their control: An overview. Platin. Met. Rev., 52(1): 23-37. https://doi.org/10.1595/147106708x248750

[4] Tiwari, D.R., Sinha, G.P. (2014). Performance and emission study of LPG diesel dual fuel engine. Int. J. Eng. Adv. Technol., 3(3): 198-203.

[5] Nemoianu, L., Pana, C., Negurescu, N., Cernat, A., Fuiorescu, D., Nutu, C. (2018). On LPG use at diesel engine: Pollutant emissions level and cycle variability aspects. IOP Conference Series: Materials Science and Engineering, 444(7): 1-7. https://doi.org/10.1088/1757899X/444/7/072002

[6] Rosha, P., Bharj, R.S., Gill, K.J.S. (2014). Performance and emission characteristics of Diesel + LPG dual fuel engine with exhaust gas recirculation. International Journal of Science, Engineering and Technology Research (IJSETR), 3(10): 2570-2574.

[7] Qi, D.H., Bian, Y.Z., Ma, Z.Y., Zhang, C.H., Liu, S.Q. (2007). Combustion and exhaust emission characteristics of a compression ignition engine using liquefied petroleum gas - Diesel blended fuel. Energy Conversion and Management, 48(2): 500-509. https://doi.org/10.1016/j.enconman.2006.06.013
[8] Aydin, M., Irgin, A., Çelik, M.B. (2018). The impact of diesel/LPG dual fuel on performance and emissions in a single cylinder diesel generator. Appl. Sci., 8(5): 1-14. https://doi.org/10.3390/app8050825

[9] Acharya, S.K., Jena, S.P. (2013). Performance and emission analysis of a CI engine in dual mode with LPG and karanja oil methyl ester. SAE Tech. Pap., 2013: 1-7. https://doi.org/10.1155/2013/540589

[10] Vijayabalan, P., Nagarajan, G. (2009). Performance, emission and combustion of LPG diesel dual fuel engine using glow plug. Jordan Journal of Mechanical and Industrial Engineering, 3(2): 105-110.

[11] Kumar, K.M., Azad, D. (2014). An experimental investigation of performance and emissions of LPG as dual fuel in diesel engine generator. International Journal of Engineering Research and Applications.

[12] Yuvaraj, M., Senthamilselvan, M., Louis, S.W., Kayalvizhi, V. (2018). Performance and emission characteristics of a diesel-LPG duel fuel in greeves engine. Journal of Automation and Automobile Engineering, 3(3): 18-24. https://doi.org/10.5281/zenodo.1475512

[13] Chaichan, M.T. (2011). Exhaust analysis and performance of a single cylinder diesel engine run on dual fuels mode. J. Eng., 17(4): 1-7.

[14] Rounce, P., Tsolakis, A., Leung, P., York, A.P.E. (2010). A comparison of diesel and biodiesel emissions using dimethyl carbonate as an oxygenated additive. Energy and $\quad$ Fuels, 24(9): 4812-4819. https://doi.org/10.1021/ef100103z

[15] Ambarita, H., Setyawan, E.Y., Ginting, S., Naibaho, W. (2017). Performance of a small compression ignition engine fuelled by liquified petroleum gas. IOP Conf. Ser. Mater. Sci. $\quad$ Eng., 237(1): 012011. https://doi.org/10.1088/1757-899X/237/1/012011

[16] Paczuski, M. (2016). Liquefied Petroleum Gas (LPG) as a fuel for internal combustion engines. Alternative Fuels, Technical and Environmental Conditions, 106-136. http://dx.doi.org/10.5772/61736

[17] Liu, E., Yue, S.Y., Lee, J. (1997). A Study on LPG as a Fuel For Vehicles. Research and Library Services Division Legislative Council Secretariat.

[18] Ryskamp, R. (2017). Emissions and Performance of Liquefied Petroleum Gas as a Transportation Fuel: A Review. World LPG Association.

[19] Pulkrabek, W.W. (2004). Engineering fundamentals of the internal combustion engine. J. Eng. Gas Turbines Power, 126(1): 198. https://doi.org/10.1115/1.1669459

[20] Dhakar, R., Tripathi, A., Raj, J. (2016). Use of Lpg in internal combustion engines-a state of art review. International Journal of Emerging Technologies and Innovative Research, 3(8): 58-66.

[21] Karamangil, M.I. (2007). Development of the auto gas and LPG-powered vehicle sector in Turkey: A statistical case study of the sector for Bursa. Energy Policy, 35(1): 640-649. https://doi.org/10.1016/j.enpol.2006.01.004

[22] Chiriac, R., Apostolescu, N., Niculescu, D. (2004). An experimental study of knock in a spark ignition engine fueled with LPG. SAE Technical Paper 2004-01-0976, 2004. https://doi.org/10.4271/2004-01-0976

[23] Ehsan, M., Bhuiyan, M., Naznin, N. (2003). Multi-fuel performance of a petrol engine for small scale power generation. SAE Technical Paper 2003-32-0063, 2003. https://doi.org/10.4271/2003-32-0063 
[24] Jian, D., Xiaohong, G., Gesheng, L., Xintang, Z. (2001). Study on diesel-LPG dual fuel engines. SAE Technical Paper 2001-01-3679, 2001. https://doi.org/10.4271/2001-01-3679

[25] Sudhir, C.V., Desai, V., Kumar, Y.S., Mohanan, P. (2003). Studies on influence of injection timing and diesel replacement on LPG-diesel dual-fuel engine. In Internal Combustion Engine Division Fall Technical Conference, pp. 161-166. https://doi.org/10.1115/ICEF2003-0719

[26] Ashok, B., Ashok, D.S., Kumar, R.C. (2015). LPG diesel dual fuel engine - A critical review. Alexandria Engineering Journal, 54(2): 105-126. https://doi.org/10.1016/j.aej.2015.03.002

[27] Sudhir, C., Desai, V., Kumar, S., Mohanan, P. (2003). Performance and emission studies on the effect of injection timing and diesel replacement on a 4-S LPGdiesel dual-fuel engine. SAE Technical Paper 2003-013087, 2003. https://doi.org/10.4271/2003-01-3087

[28] Jothi, M.N.K., Nagarajan, G., Renganarayanan, S. (2008). LPG fueled diesel engine using diethyl ether with exhaust gas recirculation. International Journal of Thermal Sciences, 47(4): 450-457. https://doi.org/10.1016/j.ijthermalsci.2006.06.012

[29] Sahir, S., Can, C., Can, H., Tolga, T., Murat, C. (2004). The effects of dual fuel operation on exhaust emissions in diesel engines. Teknoloji, 7(3): 455.

[30] Qi, D.H., Bian, Y.Z., Ma, Z.Y., Zhang, C.H., Liu, S.Q. (2007). Combustion and exhaust emission characteristics of a compression ignition engine using liquefied petroleum gas-Diesel blended fuel. Energy Convers. Manag., $\quad 48(2)$ : 500-509. https://doi.org/10.1016/j.enconman.2006.06.013

[31] Vijayabalan, P., Nagarajan, G. (2009). Performance, emission and combustion of LPG Diesel dual fuel. JJMIE, 3(2): 105-110.

[32] Saleh, H.E. (2008). Effect of variation in LPG composition on emissions and performance in a dual fuel diesel engine. Fuel, 87(13-14): 3031-3039. https://doi.org/10.1016/j.fuel.2008.04.007

[33] Karim, G.A. (1980). A review of combustion processes in the dual fuel engine - The gas diesel engine. Progress in Energy and Combustion Science, 6(3): 277-285. https://doi.org/10.1016/0360-1285(80)90019-2

[34] Bacci, A. (2018). Iraq Petroleum 2018 — Natural Gas
Must Be an Asset for Iraq. June 2017, 2018.

[35] Bisen, H.B., Suple, Y.R. (2013). Experimental investigations of exhaust emissions of four stroke SI engine by using direct injection of LPG and its analysis. CiteSeer $^{X}$, 3: 1600-1605.

[36] Wei, M.R., Li, S., Liu, J., Guo, G.L., Sun, Z.Y., Xiao, H.L. (2017). Effects of injection timing on combustion and emissions in a diesel engine fueled with 2,5dimethylfuran-diesel blends. Fuel, 192(8): 208-217. https://doi.org/10.1016/j.fuel.2016.11.084

[37] Ngang, E.A., Ngayihi Abbe, C.V. (2018). Experimental and numerical analysis of the performance of a diesel engine retrofitted to use LPG as secondary fuel. Applied Thermal Engineering, 136: 462-474. https://doi.org/10.1016/j.applthermaleng.2018.03.022

[38] Goto, S., Lee, D., Wakao, Y., Honma, H., Mori, M., Akasaka, Y., Hashimoto, K., Motohashi, M., Konno, M. (1999). Development of an LPG DI diesel engine using cetane number enhancing additives. SAE Technical Paper 1999-01-3602, 1999. https://doi.org/10.4271/1999-01-3602.

[39] Cao, J., Bian, Y., Qi, D., Cheng, Q., Wu, T. (2004). Comparative investigation of diesel and mixed liquefied petroleum gas/diesel injection engines. Proceedings of the Institution of Mechanical Engineers Part D Journal of Automobile Engineering, 218(5): 557-565. https://doi.org/10.1243/095440704774061219

\section{NOMENCLATURE}

CNG Compressed natural gas

LPG Liquefied petroleum gas

D-100 Diesel fuel

LPG-25 LPG 25\% + Diesel 75\%

LPG-50 LPG 50\% + Diesel 50\%

LPG-75 LPG 75\% + Diesel 25\%

ECU Electronic control unit

GDI Gasoline direct injection

HC Hydrocarbon

NOx Nitrogen oxide

$\mathrm{CO}_{2} \quad$ CARBON DIOXIDE EMISSIONS

CO CARBON MONOXIDE EMISSIONS

$\mathrm{O}_{2} \quad$ Oxygen 